\section{Vasilij Sidor, Svitlana Usatiuk, Olena Tyshchenko, Iryna Baranovska}

\title{
STUDY OF THE EFFECT OF ELECTROMAGNETIC FIELD AND RADIATION ON THE INTENSIFICATION OF BREWING PROCESSES
}

The object of research is the enzymatic preparations Termamil and San-Super, malt and yeast. One of the most problematic places is that the action of the magnetic field and radiation can both stimulate the amylase activity of barley malt and cause its deactivation.

During the study, a certain number of electrophysical factors were used, namely: laser radiation, which was carried out using a helium-neon laser, ultraviolet radiation - using a nitrogen gas laser, $X$-rays, a constant uniform magnetic field, ultrasound.

Results have been obtained that confirm the positive effect of the magnetic field on the activation of the amyloletic activity of concentrated preparations. A study was also conducted in accordance with the effect of electromagnetic waves on the activation of enzymes in barley and wheat malt, which showed a positive effect. This is ensured by the fact that in the course of the study, thanks to experiments, the best duration of irradiation with electromagnetic waves and different types of radiation for enzyme preparations, malt and yeast was found. These methods have a number of features. This is the availability of the appropriate equipment and knowledge of the individual types of rays, magnetic fields and electromagnetic waves, and their potential effects on enzymes, as well as control of the exposure time and magnetic field load.

Due to the action of electromagnetic waves and radiation, for a certain amount of time, it is possible to obtain an increased activity of enzymatic preparations. Compared to the fermentative preparations Termamil and SanSuper, malt and yeast, which are not susceptible to the load of magnetic fields, electromagnetic waves and various types of radiation, the fermentative preparations Termamil and San-Super, malt and yeast, which were susceptible to the action of electromagnetic waves, as well as radiation show increased activity of action. At the same time, these preparations reduce the amount of costs and increase the yield of finished products, which will serve as a positive aspect for the economic sphere of the enterprise.

Keywords: electromagnetic irradiation, biological environment, enzyme preparations Termamil and San-Super, amylolytic activity.

Sidor, V., Usatiuk, S., Tyshchenko, O., Baranovska, I. (2021). Study of the effect of electromagnetic field and radiation on the intensification of brewing processes. Technology Audit and Production Reserves, 2 (3 (58)), 44-46. doi: http://doi.org/10.15587/2706-5448.2021.230367

\section{Introduction}

The superiority of the influence of physical factors for the intensification of technological processes for the manufacture of food is considered ecological cleanliness and ease of use, in addition, the likelihood of non-contact influence on the biological environment during exposure to biochemical, chemical and enzymatic reactions. At the same time, under the influence of physical factors, various reactions often occur to food products, which positively fight back on technological processes. However, this effect has the ability to be both stimulating and inhibitory. As a result of the influence of the physiological factor on the technological process in biological media, they can be suppressed or stimulated [1-3].
The likelihood of using physical factors, such as an electromagnetic field, ultrasound (US), X-ray, laser, visible and ultraviolet (UV) wavelengths, UV rays, microwave (microwave) radiation for a stimulating effect on the biological environment has been studied by many researchers in their works, for example, in $[4,5]$.

Therefore, it is relevant to study the effect of electromagnetic fields and different types of radiation on the activation of concentrated enzyme preparations Termamil and San-Super, malt and yeast. Since, in the long term, this will lead to an increase in the output of finished products, reduce the costs of enterprises, and also improve the quality of finished products for which enzyme preparations are used. For example, in the beer industry, where barley malt, wheat malt and malt blends are used. 
And the increased activity of yeast will be used in the bakery industry $[6,7]$.

Thus, the object of research is the enzymatic preparations Termamil and San-Super, malt and yeast.

The aim of research is to determine effective modes of exposure to the entire spectrum of electromagnetic fields and radiation in the direction of stimulating the enzymatic activity of malt and enzyme preparations Termamil and San-Super and yeast.

\section{Methods of research}

The following electrophysical factors were used for research:

- laser radiation using a helium-neon laser with $\lambda=633 \mathrm{~nm}$. At a power of $1 \mathrm{~mW}$, the treatments were performed in the interval from 10 to $120 \mathrm{~s}$. Optimal, the best indicators were obtained when the samples were irradiated for $30 \mathrm{~s}$;

- ultraviolet radiation using a nitrogen gas laser at $\lambda=3.378 \cdot 10^{-7} \mathrm{~m}$ from $30 \mathrm{~s}$ to $15 \mathrm{~min}(5-8 \mathrm{~min})$;

- X-ray radiation at $\lambda=1.542 \cdot 10^{-10} \mathrm{~m}$ from $30 \mathrm{~s}$ to

$5 \min (2 \min )$;

- constant uniform magnetic field with a strength of $20.0-80.0 \mathrm{kA} / \mathrm{m}$ from 1 to $25 \mathrm{~min}$;

- microwave radiation with a power of $0-3 \mathrm{~kW}$ at a frequency of $1800-2450 \mathrm{MHz}$ from $5 \mathrm{~s}$ to $30 \mathrm{~min}$ (3-5 min);

- ultrasound with a frequency of $44 \mathrm{~Hz}$ from

5 min to 15 min.

\section{Research results and discussion}

Based on the results of studies of the effect of a constant magnetic field on the amylolytic activity of the enzyme substances Termamil and SanSuper for the intensification of the processes of dissolution, dextrinization and saccharification of starch of grain raw materials, it was found that the activation of the amylolytic activity of concentrated enzyme substances by a magnetic field has a positive effect. Studies have established that at a constant magnetic field strength of $75 \mathrm{kA} / \mathrm{m}$ and an exposure duration of 5 minutes for the concentrated enzyme Termamil, its activity increases by $10.4 \%$. With the same processing criteria for the concentrated San-Super enzyme preparation, its activity increased by $14.6 \%$ in comparison with the control.

In addition, the effect of these factors on the activity of enzymes in barley malt for beer production was studied. Studies have established that the optimal voltage of a constant magnetic field to stimulate barley malt amylases is $75 \mathrm{kA} / \mathrm{m}$, with duration of 4-5 minutes. According to the research results, the content of maltose in the wort as a product of starch hydrolysis under the influence of $\beta$-amylases - the maximum values are reached after 4 minutes of irradiation. The maltose content in the wort was determined by the WiltstatterSchudel method (aldose oxidation). The results are shown in Fig. 1 [8].

Consequently, treatment with physiological factors makes it possible to achieve the maximum transfer of starch hydrolysis products into solution at the lowest malt consumption and without the use of concentrated enzyme substances [9, 10].

In addition, studies of the effect of electromagnetic waves on the activation of enzymes in barley and wheat malt have been carried out. The objects of study are aqueous solutions of crushed grain products (mash) prepared by 4 methods:

1) pure malt (malt);

2) with the addition of unmalted raw materials - barley (malt + barley flour);

3) malt + wheat flour;

4) malt + corn grits.

The radiation source is $\mathrm{X}$-rays at $\lambda=1.542 \cdot 10^{-10} \mathrm{~m}$ duration from $30 \mathrm{~s}$ to $10 \mathrm{~min}$. The results of the experiments are shown in Fig. 2.

According to Fig. 2, it can be concluded that irradiation for 2 minutes is sufficient to activate the enzymes of the malt and the mixture of malt and unmalted substances.

A necessary factor in the intensification of many technological, including biotechnological, processes is considered to be electromagnetic waves - waves that affect the growth, reproduction and fermentation energy of yeast-like fungi [11]. In the course of the study, the time dependence of the effect of X-ray radiation on the characteristics of the dependence of the degree of activation of the cell structures of the yeast culture of Saccharomyces cerevisiae was investigated and determined, which is shown in Table 1.

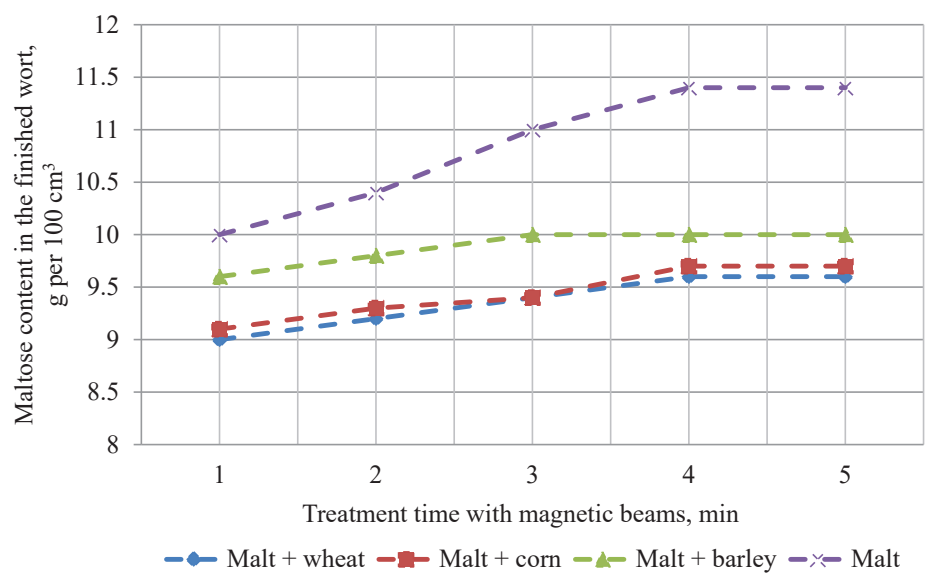

Fig. 1. Dynamics of the content of maltose when using a constant magnetic field

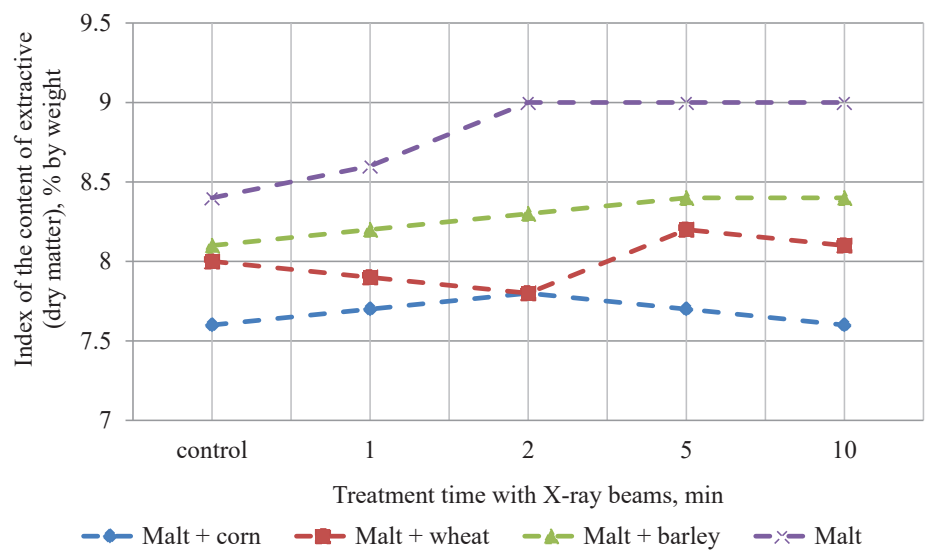

Fig. 2. Dynamics of accumulation of wort extractives under the influence of $\mathrm{X}$-rays 
Table 1

Influence of ultraviolet radiation on the activity of Saccharomyces cerevisiae

\begin{tabular}{|l|c|c|}
\hline \multicolumn{1}{|c|}{ Sample } & $\begin{array}{c}\text { Irradiation } \\
\text { duration, min }\end{array}$ & $\begin{array}{c}\text { Average number of Saccharamyces } \\
\text { cerevisiae colonies, CFU.10 } / \mathrm{cm}^{3}\end{array}$ \\
\hline Control sample & 0 & 92 \\
\hline \multirow{3}{*}{ X-ray irradiation } & 5 & 185 \\
\cline { 2 - 3 } & 10 & 92 \\
\cline { 2 - 3 } & 15 & 87 \\
\cline { 2 - 3 } & 20 & 64 \\
\hline
\end{tabular}

The object of research was also the yeast Saccharomyces cerevisiae of the Saflager W-34/70 race, which was grown on a solid nutrient medium wort agar at a temperature of $28{ }^{\circ} \mathrm{C}$ for 24 hours. For irradiation, ultraviolet radiation was used with a nitrogen gas laser at a wavelength of $\lambda=3.378 \cdot 10^{-7} \mathrm{~m}$ for $30 \mathrm{~s}$ to $15 \mathrm{~min}$.

The results of the study of processed yeast demonstrate that the electromagnetic effect brings about the formation of significant changes in yeast cells.

As a result of irradiation of yeast with a nitrogen laser, the morphological and physiological state of cells changes, accelerates the process of reproduction and significantly activates their enzymatic work, which increases zymase activity [12, 13]

Thus, to stimulate the biochemical processes of brewing during the course of chemical, biochemical and enzymatic reactions, it is recommended to use:

- ultraviolet radiation using a nitrogen gas laser at

$\lambda=3.378 \cdot 10^{-7} \mathrm{~m}$ in the range from 5 to $8 \mathrm{~min}$;

- X-rays at $\lambda=1.542 \cdot 10^{-10} \mathrm{~m}$ for $2 \mathrm{~min}$;

- constant uniform magnetic field with a strength of $80.0 \mathrm{kA} / \mathrm{m}$ for 5 minutes.

\section{Conclusions}

In the course of the study, it was found that the effect of a constant magnetic field on the amylolytic activity of the enzyme preparations Termamil and San-Super has a positive effect, namely, increasing their activity using a 5-minute constant magnetic field voltage. A similar study was also carried out on the effect of a constant magnetic field on the components of barley and wheat malt. The result of the study shows that treatment with physical factors gives the maximum solution of starch hydrolysis products, both malt and other grain products. At the same time, the amount of malt consumption is reduced and the use of concentrated enzyme preparations is excluded.

Studies of the influence of electromagnetic waves on the activation of enzymes in barley and wheat malt have been carried out. X-rays were used for the radiation source with different duration of influence. Ultimately, research has shown that the activation of enzymes in malt and malt mixtures occurs as early as the 2nd minute of irradiation.

Electromagnetic waves were also involved in the study of determining the activation of cellular structures of the yeast culture Saccharomyces cerevisiae. The results of the study demonstrate that electromagnetic exposure leads to significant changes in yeast cells. The yeast was also irradiated with a nitrogen laser. This led to an acceleration of the multiplication process, and also activated the enzymatic activity of the yeast.
The research results will be useful to a large number of entrepreneurs who in some way come into contact with the use of enzyme preparations for the production of their products.

These process enhancers and accelerators are used in a wide variety of food industries. And the results of this study demonstrate that their activity can be cleaned by using an electromagnetic field and various radiations, with the correct duration of exposure to enzyme preparations, malt and yeast.

\section{References}

1. Pahl, R., Meyer, B., Biurrun, R. (2016). Wort and Wort Quality Parameters. Brewing Materials and Processes, 113-121. doi: http:// doi.org/10.1016/b978-0-12-799954-8.00006-x

2. Eumann, M., Schaeberle, C. (2016). Water. Brewing Materials and Processes, 97-111. doi: http://doi.org/10.1016/b978-0-12799954-8.00005-8

3. Larionov, K. B., Kaltaev, A. Z., Gubin, V. E., Zenkov, A. V. (2021). Research of oxidation and pyrolysis processes of brewing industry wastes. Thermophysical Basis of Energy Technologies (TBET 2020), 37-50. doi: http://doi.org/10.1063/5.0046480

4. Popova, V., Kislaya, L., Fefelov, A. (2004). Ekstragirovanie aromaticheskikh veschestv i efirnykh masel iz rastitelnogo syrya s magnitnoy obrabotkoy. Pischevaya $i$ pererabatyvayuschaya promyshlennost, $6,28-29$.

5. Osipova, M. V., Gluschenko, L. F. (2006). Intensifikatsiya brozheniya piva posredstvom elektronno-ionnoy obrabotki (EIO) pivnykh drozhzhey. Pivo $i$ napitki, 5, 22-24.

6. Popova, V., Kislaya, L., Fefelov, A. (2004). Izmenenie fizikokhimicheskikh svoystv vodnykh sistem pod vliyaniem magnitnykh poley. Pischevaya i pererabatyvayuschaya promyshlennost, 7, $28-29$

7. Meletev, A. E., Todosiychuk, S. R., Koshevaya, V. N., Meletev, A. E. (Ed.) (2007). Tekhnokhimicheskiy kontrol proizvodstva soloda, piva $i$ bezalkogolnykh napitkov. Vinnitsa: Novaya Kniga, 392.

8. Savitskaya, Ya. A., Paslen, V. V. (2009). Vliyanie vysokochastotnykh elektromagnitnykh poley na organizm cheloveka. Ekologiya ta noosferologiya. 20 (1-2), 38-43.

9. Kovaleva, A. V. (2009). Vliyanie elektromagnitnykh poley i izlucheniy na bioobekty. Aktualni pitannya biologii, ekologii ta khimii: elektronne naukove fakhove vidannya, 1 (1), 64-85.

10. Martynyuk, V. S., Tseysler, Yu. V., Temuryants, N. A. (2012). Interference of mechanism of weak extremely low frequency electromagnetic fields influence on man and animals. Geofizicheskie protsessy i biosfera, 11 (2). 16-39.

11. Kucharczyk, K., Tuszyński, T. (2017). The effect of wort aeration on fermentation, maturation and volatile components of beer produced on an industrial scale. Journal of the Institute of Brewing, 123 (1), 31-38. doi: http://doi.org/10.1002/jib.392

12. Burlaka, N. I., Gozhenko, S. S. (2010). Electromagnetic field, his kinds, descriptions, classification and influence on population's health. Aktualnye problemy transportnoy meditsiny, 2 (4 (22)), $24-32$.

13. Kovalova, O. V. (2009). Vplyv na orhanizm liudyny elektromahnitnykh poliv antropohennoho pokhodzhennia. Visnyk Zaporizkoho natsionalnoho universytetu. Biolohichni nauky, 2, 96-104.

Vasilij Sidor, PhD, Associate Professor, Department of Food Expertise, National University of Food Technologies, Kyiv, Ukraine, ORCID: https:// orcid.org/0000-0002-4139-4101,e-mail: som58@ukr.net

Svitlana Usatiuk, PhD, Associate Professor, Department of Food Expertise, National University of Food Technologies, Kyiv, Ukraine, ORCID: https://orcid.org/0000-0001-7554-0827, e-mail: esmeraldo@ukr.net

Olena Tyshchenko, Senior Lecturer, Department of Hotel and Restaurant Business, National University of Food Technologies, Kyiv, Ukraine, ORCID: https://orcid.org/0000-0001-9383-1898, e-mail: olena.m.tyshchenko@gmail.com

Iryna Baranovska, Department of Food Expertise, National University of Food Technologies, Kyiv, Ukraine, ORCID: https://orcid.org/ 0000-0003-0033-4425, e-mail: irabaranovskaya71@gmail.com 